\title{
Farnesoid $X$ receptor signal is involved in deoxycholic acid-induced intestinal metaplasia of normal human gastric epithelial cells
}

\author{
SHU LI, XIN CHEN, LU ZHOU and BANG-MAO WANG \\ Department of Gastroenterology and Hepatology, Tianjin General Hospital, Tianjin Medical University, \\ Heping, Tianjin 300052, P.R. China
}

Received April 1, 2015; Accepted July 21, 2015

DOI: $10.3892 / o r .2015 .4207$

\begin{abstract}
The farnesoid X receptor (FXR) signaling pathway is known to be involved in the metabolism of bile acid, glucose and lipid. In the present study, we demonstrated that $400 \mu \mathrm{mol} / 1$ deoxycholic acid (DCA) stimulation promotes the proliferation of normal human gastric epithelial cells (GES-1). In addition, DCA activated FXR and increased the expression of intestinal metaplasia genes, including caudal-related homeobox transcription factor $2(C d x 2)$ and mucin $2(M U C 2)$. The treatment of FXR agonist GW4064/antagonist guggulsterone (Gug.) significantly increased/decreased the expression levels of FXR, Cdx 2 and MUC2 protein in DCA-induced GES- 1 cells. GW4064/Gug. also enhanced/reduced the nuclear factor- $\kappa \mathrm{B}$ $(\mathrm{NF}-\kappa \mathrm{B})$ activity and binding of the $\mathrm{Cdx} 2$ promoter region and $\mathrm{NF}-\kappa \mathrm{B}$, the most common subunit p50 protein. Taken together, the results indicated that DCA is capable of modulating the expression of $\mathrm{Cdx} 2$ and the downstream MUC2 via the nuclear receptor FXR-NF- $\mathrm{BB}$ activity in normal gastric epithelial cells. FXR signaling pathway may therefore be involved in the intestinal metaplasia of human gastric mucosa.
\end{abstract}

\section{Introduction}

The abnormalities of various genes, and multiple signaling pathways were reported to be involved in the gastric cancer, a type of gastric epithelial malignancy (1-3). When subjected to various external stimuli, normal gastric mucosa suffers from gradual and piecemeal changes, including chronic inflammation, atrophy, intestinal metaplasia, dysplasia and tumorigenesis (1-3). Early detection, diagnosis and treat-

Correspondence to: Professor Bang-Mao Wang, Department of Gastroenterology and Hepatology, Tianjin General Hospital, Tianjin Medical University, 154 Anshan Road, Heping, Tianjin 300052, P.R. China

E-mail: bangmao_wang_tijmu@163.com

Key words: farnesoid $\mathrm{X}$ receptor, caudal-related homeobox transcription factor 2 , mucin 2, deoxycholic acid, intestinal metaplasia, human gastric epithelial cells, NF- $\kappa \mathrm{B}$ ment are crucial for the prognosis of patients with gastric cancer (1-3). Chronic atrophic gastritis (CAG) with intestinal metaplasia is an important precancerous lesion of gastric mucosa $(2,3)$. The main type of gastric cancer is the intestinal type, which is associated with several factors, such as Helicobacter pylori $(\mathrm{Hp})$ infection, radiation, and chronic bile reflux (1-4). Bile acid-containing gastric and duodenal reflux induces the chronic inflammation of gastric mucosa and subsequently gastric intestinal metaplasia $(4,5)$. Deoxycholic acid (DCA), secondary bile acid, is a type of carcinogenic factor of the gastrointestinal tract and has received increasing attention (5-7).

Farnesoid X receptor (FXR) is a member of the nuclear hormone receptor superfamily and is involved in the homeostasis of bile acid, cholesterol and lipid (8-10). Bile acid, as an endogenous ligand, can induce FXR activation, which is involved in the abnormal growth of the digestive tract, chronic inflammatory disease, metabolic disease and carcinogenesis (7-12).

Caudal-related homeobox transcription factor $2(\mathrm{Cdx} 2)$ and mucin 2 (MUC2) are regarded as two key modulators of intestinal metaplasia (7,13-16). Cdx2, a key intestine-specific nuclear transcription factor, regulates the expression of genes on nutrient digestion and absorption, and plays an important role in the intestinal mucosa, epithelial cell differentiation, proliferation and the maintenance of early differentiation characteristics $(13,15,17) . \mathrm{Cdx} 2$ is expressed from the early stages of embryonic development to mature individuals. $\mathrm{Cdx} 2$ expression was reported to occur in intestinal epithelium from endodermal, but not normal gastric mucosa $(7,18)$. However, accumulating evidence indicated that $\mathrm{Cdx} 2$ is also expressed in CAG-associated gastric intestinal metaplasia, Barrett's esophagus and some sections of gastric cancer (13,14,19-21). In a $\mathrm{Cdx} 2$ transgenic mouse model, the overexpression of $\mathrm{Cdx} 2$ induces morphologically the occurrence of the intestinal metaplasia in gastric mucosa $(19,22,23)$. Such ectopic expression of $\mathrm{Cdx} 2$ protein is considered an important initial factor or switching for intestinal metaplasia of gastric mucosa, and may modulate the differentiation process of intestinal epithelial cells.

As a specific marker of intestinal epithelial goblet cell, secreted MUC2 protein is involved in the renewal and 
differentiation of epithelial cells and the maintenance of epithelial integrity $(24,25)$. MUC2 protein is located downstream of the $\mathrm{Cdx} 2$ protein and can be regulated by $\mathrm{Cdx} 2$ (26). It was reported that the treatment of chenodeoxycholate (CDCA) on gastric epithelial RGM-1 cells in mice induces the ectopic expression of $\mathrm{Cdx} 2$ and MUC2 protein (7). However, the role of bile acid-FXR pathway in normal human gastric mucous epithelial GES-1 cells model remains to be elucidated.

The present study focused on the DCA-treated normal human GES-1 gastric mucosa cells at different concentrations for different time periods, and then analyzed cell proliferation and the role of FXR in gastric intestinal metaplasia. We found that DCA stimulated GES-1 cell growth and induced an increase in the expression levels of intestinal metaplasia genes in a time- and dose-dependent manner, including $F X R, C d x 2$ and $M U C 2$, via nuclear receptor FXR-NF- $\mathrm{BB}$ activity.

\section{Materials and methods}

Cells and treatments. Normal human gastric epithelial cells (GES-1) were purchased from the Beijing Institute for Cancer Research (China) and cultured in Roswell Park Memorial Institute 1640 (RPMI-1640) at $37^{\circ} \mathrm{C}$ with $5 \% \mathrm{CO}_{2}$, supplemented with $10 \%$ fetal bovine serum (FBS), $100 \mathrm{U} / \mathrm{ml}$ penicillin and $100 \mu \mathrm{g} / \mathrm{ml}$ streptomycin (Gibco-BRL, Grand Island, NY, USA) in a humidified incubator. The GES-1 cells were untreated or treated with DCA $(50,200,400,600$ and 1,000 $\mu \mathrm{mol} / \mathrm{l})$, $400 \mu \mathrm{mol} / 1$ DCA plus $1.0 \mu \mathrm{mol} / 1 \mathrm{GW} 4064$ (FXR agonist) or $400 \mu \mathrm{mol} / 1 \mathrm{DCA}$ plus $50 \mu \mathrm{mol} / \mathrm{l}$ guggulsterone (Gug.) (FXR antagonist) for different time points, respectively.

3-(4,5-Dimethylthiazol-2-yl)-5-(3-carboxymethoxyphenyl)-2(4-sulfophenyl)-2H-tetrazolium (MTS) assay. The MTS assay was performed to measure GES-1 cell proliferation, using an ELISA microplate reader Multiskan (Thermo Labsystems, Beverly, MA, USA), according to the manufacturer's instructions. Briefly, the cells were cultured in 96-well plates and treated with the indicated dose of DCA. After incubation with $20 \mu \mathrm{l}$ MTS solution (Promega, Madison, WI, USA) for $4 \mathrm{~h}$ at $37^{\circ} \mathrm{C}$, the absorbance value at $490 \mathrm{~nm}$ was measured.

Annexin V-fluorescein isothiocyanate (FITC)/propidium iodide (PI) staining and flow cytometry. The apoptosis of DCA-treated GES-1 cells was assessed by flow cytometry, after double staining with Annexin V-FITC and PI using an apoptosis detection kit (Solarbio Life Sciences, Beijing, China). Briefly, $1 \times 10^{6}$ GES-1 cells/ml were washed gently with cold PBS solution, and incubated with $10 \mu \mathrm{l}$ Annexin V-FITC and $10 \mu \mathrm{PI}$ in binding buffer for $15 \mathrm{~min}$, according to the manufacturer's instructions. Flow cytometry was then performed, using the Guava easyCyte system (Millipore, Billerica, MA, USA).

Terminal transferase dUTP nick end-labeling (TUNEL) assay. A TUNEL assay was performed to measure the apoptosis of simulated GES-1 cells, using a peroxidase In Situ Cell Death Detection kit (Roche, Germany), according to the manufacturer's instructions. Briefly, GES-1 cells were cultured on coverslips and fixed in $4 \%$ formaldehyde. The TUNEL reaction mix was then added. The apoptosis index (AI) was calculated by the ratio of TUNEL-positive cells to total cells.
Western blotting. Western blotting was performed to detect the expression levels of FXR, Cdx2 and MUC2 proteins. Briefly, total cell lysates of GES-1 were harvested using Nonidet P-40 buffer [50 mM Tris- $\mathrm{HCl}$ ( $\mathrm{pH}$ 7.6), 0.5\% Nonidet P-40, $0.1 \mathrm{mM}$ EDTA, $300 \mathrm{mM} \mathrm{NaCl}, 20 \%$ glycerol, $1 \mathrm{mM}$ sodium butyrate, $0.1 \mathrm{mM}$ sodium orthovanadate], supplemented with protease inhibitor mixture (Roche Applied Science, Indianapolis, IN, USA) for $10 \mathrm{~min}$ on ice. The protein samples were resolved using SDS-PAGE and then transferred to ImmunoBlot polyvinylidene fluoride membranes (Millipore) by semi-dry electroblotting. The membranes were blocked with $5 \%$ non-fat dry milk for $2 \mathrm{~h}$ and incubated with primary antibodies overnight at $4^{\circ} \mathrm{C}$. The primary antibodies used were: rabbit anti-FXR (Santa Cruz Biotechnology, Inc., Santa Cruz, CA, USA), rabbit antiCdx2 (Cell Signaling Technology, Beverly, MA, USA), mouse anti-MUC2 (Sigma-Aldrich, St. Louis, MO, USA), mouse antiGAPDH (Zhongshan Jinqiao, Beijing, China) antibodies. After washing, the membranes were visualized with an enhanced chemiluminescence detection kit (Amersham Biosciences, Pittsburgh, PA, USA) using horseradish peroxidase-conjugated goat anti-rabbit or anti-mouse secondary antibodies (Bio-Rad, Hercules, CA, USA). Band density in the western blot assay was digitized with TotalLab software (Tyne and Wear, UK) and normalized to GAPDH protein.

Luciferase reporter assay. GES-1 cells were cultured and co-transfected with pNF- $\kappa \mathrm{B}$-Luc plasmid (Clontech, Palo Alto, CA, USA) and pRL-TK (Promega), using Lipofectamine 2000. After $18 \mathrm{~h}$, cells were treated or not treated with $400 \mu \mathrm{mol} / \mathrm{l}$ DCA, $400 \mu \mathrm{mol} / 1 \mathrm{DCA}$ plus $1.0 \mu \mathrm{mol} / 1 \mathrm{GW} 4064$ or $400 \mu \mathrm{mol} / 1$ DCA plus $50 \mu \mathrm{mol} / 1 \mathrm{Gug}$. for $6 \mathrm{~h}$, and then luciferase activity was assessed with a dual luciferase reporter assay kit (Promega), according to the manufacturer's instructions. Each assay was performed in triplicate and repeated at least three times.

Chromatin immunoprecipitation (ChIP) assay. The GES-1 cells were untreated (control group) or treated with $400 \mu \mathrm{mol} / 1 \mathrm{DCA}, 400 \mu \mathrm{mol} / 1 \mathrm{DCA}$ plus $1.0 \mu \mathrm{mol} / 1 \mathrm{GW} 4064$, or $400 \mu \mathrm{mol} / 1 \mathrm{DCA}$ plus $50 \mu \mathrm{mol} / \mathrm{l} \mathrm{Gug}$. for $6 \mathrm{~h}$, respectively. Formaldehyde $(1 \%)$ was added to the treated or untreated GES-1 cells at $37^{\circ} \mathrm{C}$ for $10 \mathrm{~min}$. Glycine (125 mM) ( $\mathrm{pH} \mathrm{7.0)}$ was used to stop the cross-linking. The nuclear extracts were then prepared and $10 \%$ extracts were saved as input. The expression levels of input for p50 or p65 protein were detected by western blotting, using rabbit anti-p65 (Cell Signaling Technology), rabbit anti-p50 (Cell Signaling Technology), or rabbit anti-histone $\mathrm{H} 3$ (Abcam, Cambridge, UK) as a nuclear control. Additional extracts were precleared with protein $\mathrm{G}$ Dynabeads (Invitrogen-Life Technologies, Carlsbad, CA, USA) and immunoprecipitated with rabbit anti-p65, anti-p50, or rabbit IgG (Sigma-Aldrich) antibodies, and then the protein G Dynabeads (Invitrogen-Life Technologies). Dynabeads were washed three times with buffer containing $10 \mathrm{mM}$ Tris- $\mathrm{HCl}$ (pH 8.0), $140 \mathrm{mM} \mathrm{NaCl}, 1 \mathrm{mM}$ EDTA, $0.1 \%$ Triton X-100 and once with TE buffer (10 mM Tris-HCl, pH 8.0, 1 mM EDTA). Dynabeads were divided into two portions. In one portion, the chromatin fragments were eluted from dynabeads with elution buffer containing $62.5 \mathrm{mM}$ Tris- $\mathrm{HCl}$ (pH 6.8), $200 \mathrm{mM} \mathrm{NaCl}$, $2 \%$ SDS, $10 \mathrm{mM}$ dithiothreitol and crosslinks were reverted by heating at $65^{\circ} \mathrm{C}$ overnight. In the other portion, the amount of 
A

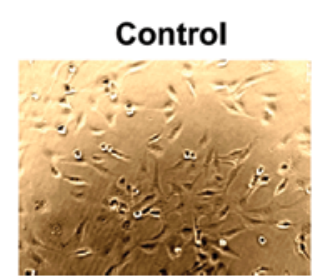

$200 \mu \mathrm{mol} / \mathrm{I} \mathrm{DCA}$

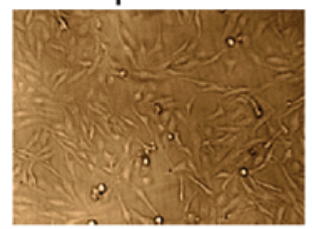

$600 \mu \mathrm{mol} / / \mathrm{DCA}$

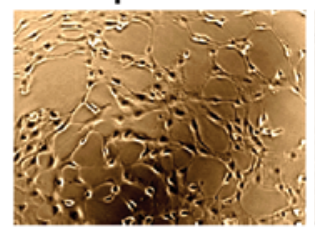

B

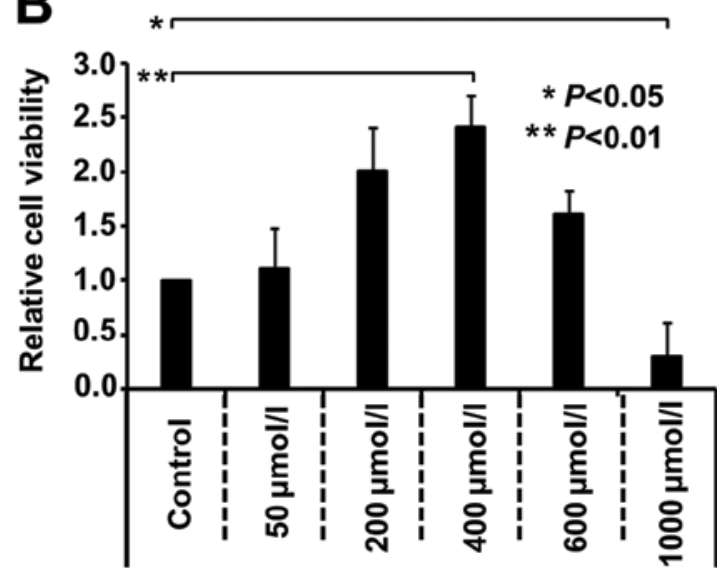

Control

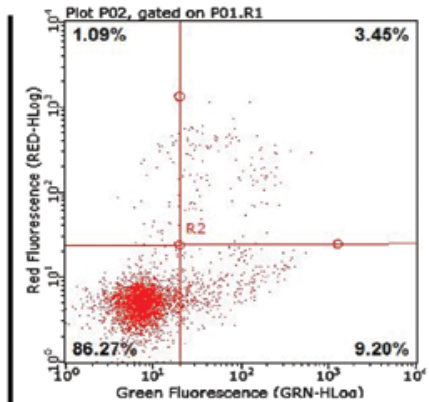

$200 \mu \mathrm{mol} / / \mathrm{IDCA}$

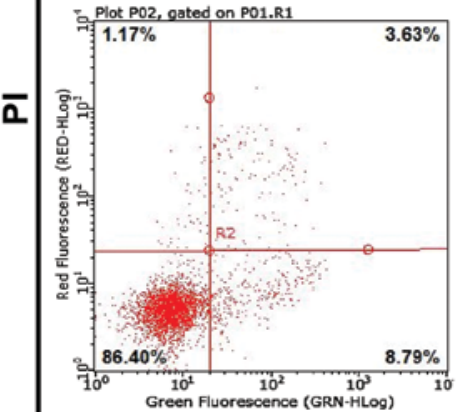

$600 \mu \mathrm{mol} / / \mathrm{DCA}$

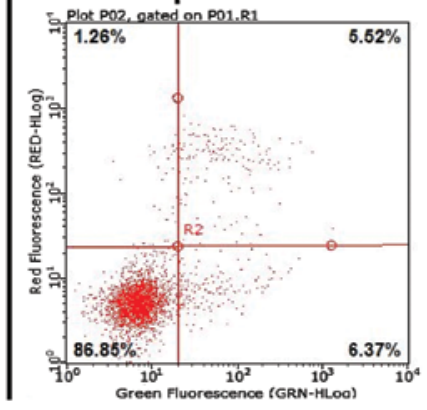

$50 \mu \mathrm{mol} / \mathrm{I} \mathrm{DCA}$

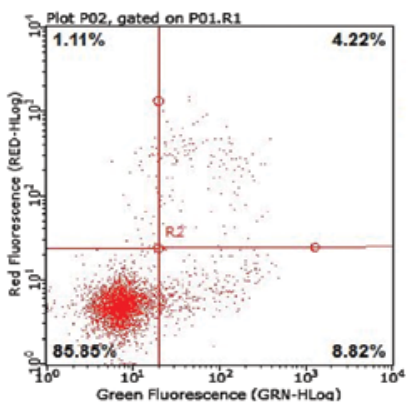

$400 \mu \mathrm{mol} / / \mathrm{DCA}$

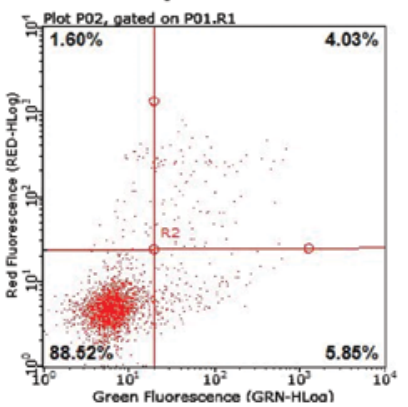

$1000 \mu \mathrm{mol} / \mathrm{I} \mathrm{DCA}$

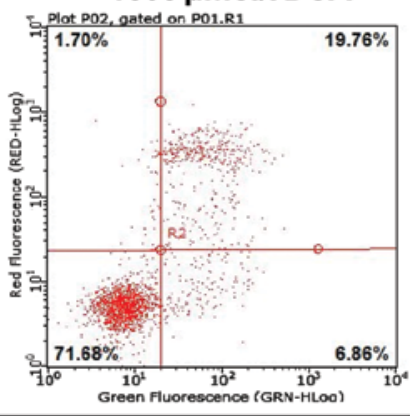

Annexin V-FITC

Figure 1. DCA affects the proliferation and apoptosis of GES-1 cells in a dose-dependent manner. The GES-1 cells were cultured and treated with the DCA agent with the indicated concentrations (50, 200, 400, 600 and 1,000 $\mu \mathrm{mol} / \mathrm{l})$ or not (control) for $24 \mathrm{~h}$, respectively. (A) Images of cells in different groups. (B) Cell proliferation was measured by an MTS assay. One-way analysis of variance (ANOVA) was performed, and significant differences were indicated as: ${ }^{*} \mathrm{P}<0.05,{ }^{* *} \mathrm{P}<0.01$. (C) Cell apoptosis was also measured by Annexin V-FITC/PI staining, followed by flow cytometry. DCA, deoxycholic acid; GES-1, gastric epithelial cells.

enriched p65 or p50 protein was analyzed by the western blot analysis and TotalLab software.

DNA was extracted with phenol/chloroform and ethanol precipitated from the chromatin fragments and input fraction. The amount of bound $C d x 2$ promoter fragments was measured with a FastStart Universal SYBR-Green Master (Rox) (Roche Diagnostics, Basel, Switzerland) using an Applied Biosystems 7900 Fast Real-Time PCR system (Applied Biosystems, Foster City, CA, USA). The primer sequences targeting the promoter region of human $C d x 2$ gene (NM_001265, position from -371 to -234) were used: 5'-CCTCGACGTCTCCAACCAT-3' (forward) and 5'-CCA CTAGGCTGCAGAGGC-3' (reverse). The $\Delta \mathrm{Ct}$ value of the immunoprecipitated $C d x 2$ promoter fragment was normalized to the input fraction $\mathrm{Ct}$ value in the same assay. The $\Delta \Delta \mathrm{Ct}$ value was then determined by subtracting the $\Delta \mathrm{Ct}$ (normalized anti-IgG group) from the $\Delta \mathrm{Ct}$ (normalized anti-p65 or p50 group). Relative binding amount of $C d x 2$ promoter fragment was calculated by raising 2 to the power of the negative- $\Delta \Delta \mathrm{Ct}$ and then normalized to the amount of enriched p65 or p50 protein. The level of control group was set on 1 .

Statistical analysis. Data were presented as the means $\pm \mathrm{SE}$ (standard error). SPSS 16.0 software was used to perform one-way analysis of variance (ANOVA) and followed multiple mean comparisons using the Student-Newman-Keuls test. $\mathrm{P}<0.05$ was considered statistically significant for all the analyses. The experiments were repeated three times.

\section{Results}

Effect of DCA on the proliferation and apoptosis of the GES-1 cells. To determine the effect of DCA stimulation on the proliferation of GES-1, the cells were cultured in vitro and then treated with DCA $(0,50,200,400,600$ and 1,000 $\mu \mathrm{mol} / \mathrm{l})$ for $24 \mathrm{~h}$, respectively. As shown in Fig. 1A, evident proliferation, strong refraction and exteremely few exfoliated cells were 
observed in 50, 200 and $400 \mu \mathrm{mol} / 1 \mathrm{DCA}$ groups. Although the number of exfoliated cells and intercellular space increased, cell refractive difference decreased in 600 and 1,000 $\mu \mathrm{mol} / 1$ DCA groups. Notably, cytoplasmic vacuoles increased and the cell membranes ruptured in some DCA (600 and $1,000 \mu \mathrm{mol} / \mathrm{l}$ )-treated GES-1 cells. The proliferation of cells was then analyzed by an MTS assay. The data in Fig. 1B show that DCA stimulation promoted the proliferation of normal human GES-1 cell in a dose-dependent manner. Compared with the $0 \mu \mathrm{mol} / 1$ control group, the highest reproductive rate of GES-1 cells was detected in the $400 \mu \mathrm{mol} / 1$ group $(\mathrm{P}<0.01)$. The treatment of $1,000 \mu \mathrm{mol} / 1 \mathrm{DCA}$ for $24 \mathrm{~h}$ resulted in a decrease of GES-1 cell proliferation $(\mathrm{P}<0.05)$. Furthermore, the potential apoptotic mode of DCA-treated GES-1 cells was evaluated by double staining with FITC-conjugated annexin V/PI, followed by flow cytometry. As shown in Fig. 1C, after exposure to 1,000 $\mu \mathrm{mol} / 1 \mathrm{DCA}$, increased GES-1 cells underwent late apoptosis or necrosis $(19.76 \%$, Annexin V-FITC+/PI+), compared with the control group (3.45\%). However, the treatment of 50, 200, 400 and $600 \mu \mathrm{mol} / 1 \mathrm{DCA}$ failed to efficiently induce apoptosis of the GES-1 cells.

In addition, the MTS and TUNEL assays were performed in GES-1 cells under the treatment of $400 \mu \mathrm{mol} / 1 \mathrm{DCA}$ for different time points $(0,3,6,12,24,48$ and $72 \mathrm{~h})$. As shown in Fig. 2A, the highest reproductive rate was detected in the $6 \mathrm{~h}$ group $(\mathrm{P}<0.01)$, whereas the lowest reproductive rate was detected in the $72 \mathrm{~h}$ group $(\mathrm{P}<0.05)$, compared with the $0 \mathrm{~h}$ group. A reverse trend was observed in the apoptosis level of GES-1 cells. As shown in Fig. 2B, compared with the $0 \mathrm{~h}$ group, the $400 \mu \mathrm{mol} / 1 \mathrm{DCA}$ for 48 and $72 \mathrm{~h}$ induced the apoptosis of GES-1 cells, whereas $400 \mu \mathrm{mol} / 1 \mathrm{DCA}$ for $6 \mathrm{~h}$ reduced cell apoptosis $(\mathrm{P}<0.05)$. The highest apoptotic rates were detectable in the $72 \mathrm{~h}$ group $(\mathrm{P}<0.01)$. These observations demonstrated that the effect of DCA on the growth of GES-1 cells exhibited duality, i.e., DCA promoted proliferation and attenuated the apoptosis of GES-1 cells in vitro under a low-moderate dose for short period of time. Inhibition of the cell proliferation and an increase of apoptosis under a high dose for a long period of time may be associated with the toxicity of DCA to GES-1 cells.

Effect of DCA on the expression of FXR, Cdx2 and MUC2 in GES-1 cells. We performed western blotting to detect the expression levels of FXR, $\mathrm{Cdx} 2$ and MUC2, to determine the role of DCA in the intestinal metaplasia and its expression in GES-1 cells. As shown in Fig. 3, when the GES-1 cells were treated with DCA $(0,50,100,200$ and $400 \mu \mathrm{mol} / \mathrm{l})$ for $6 \mathrm{~h}$, the expression of endogenous FXR, Cdx2 and MUC2 increased at the protein levels in a dose-dependent manner. Compared with the $0 \mu \mathrm{mol} / 1$ control group, the highest expression levels of FXR, Cdx2 and MUC2 protein were observed in the $400 \mu \mathrm{mol} / 1$ group $(\mathrm{P}<0.001, \mathrm{P}<0.01)$. Significantly increased expression levels of $F X R, C d x 2$ and $M U C 2$ mRNA were also observed as measured using quantitative PCR (qPCR) in the $400 \mu \mathrm{mol} / 1$ DCA-treated GES-1 cells (data no shown).

Under the treatment of $400 \mu \mathrm{mol} / 1 \mathrm{DCA}$, we also examined the expression level of FXR, Cdx2 and MUC2 in GES-1 cells at different time points $(0,3,6,12$ or $24 \mathrm{~h})$. As shown in Fig 4, compared with the $0 \mathrm{~h}$ group, the expression levels of FXR and $\mathrm{Cdx} 2$ protein increased at $3 \mathrm{~h}$, reached a maximum at

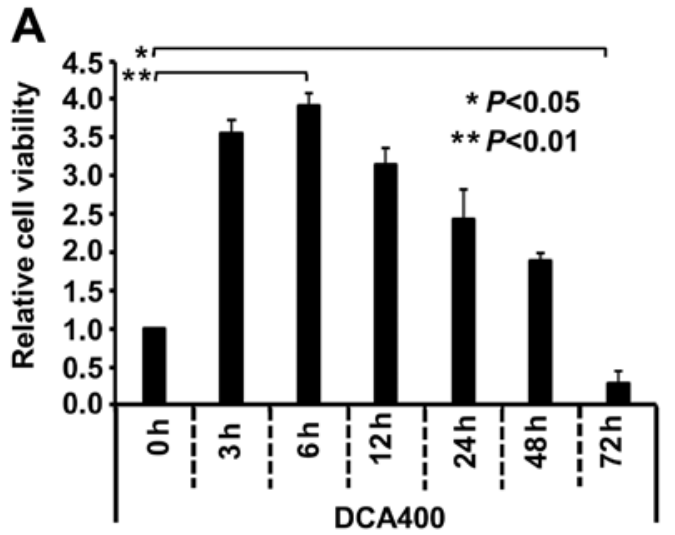

B

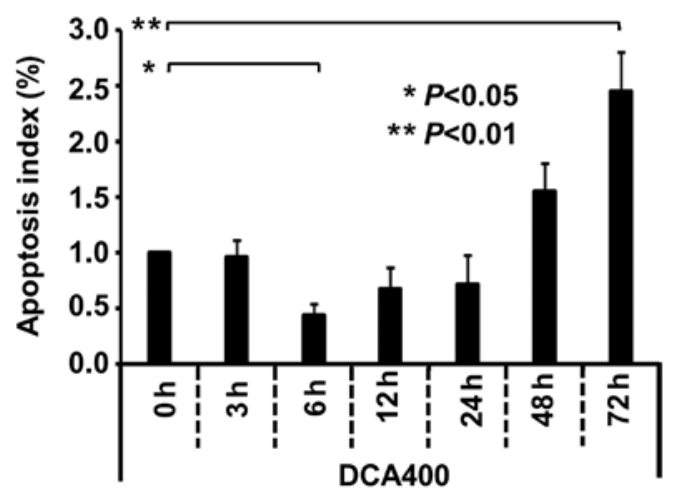

Figure 2. DCA affects the proliferation and apoptosis of GES-1 cells in a time-dependent manner. The GES-1 cells were cultured and treated with $400 \mu \mathrm{mol} / 1 \mathrm{DCA}$ for the indicated time points $(0,3,6,12,24,48$ and $72 \mathrm{~h})$, respectively. (A) Proliferation or (B) apoptosis of cells was then measured by an MTS or TUNEL assay. One-way analysis of variance was performed, and significant differences were indicated as follows: ${ }^{*} \mathrm{P}<0.05,{ }^{* *} \mathrm{P}<0.01$. DCA, deoxycholic acid; GES-1, gastric epithelial cells.

$6 \mathrm{~h}$ (Fig. 4A-C, $\mathrm{P}<0.001)$ and then decreased at 12 and $24 \mathrm{~h}$ (Fig. 4A-C, $\mathrm{P}<0.01, \mathrm{P}<0.05$ ) while MUC2 expression increased following DCA treatment, showing the highest signal at $12 \mathrm{~h}$ (Fig. 4A and $\mathrm{D}, \mathrm{P}<0.001$ ), and then decreased at $24 \mathrm{~h}$ (Fig. 4A and D, P<0.05). A similar trend was detectable when $F X R, C d x 2$ and $M U C 2$ mRNA levels were measured (data not shown). These results suggested that, after the stimulation of DCA in GES-1 cells, FXR expression increased and gradually induced the expression of $\mathrm{Cdx} 2$ and intestinal metaplasia marker MUC2.

GW4064/Guggulsterone affect the expression of FXR, Cdx2 and MUC2 in DCA-induced GES-1 cells. To provide insight into the role of FXR regulation and its downstream gene expression in the DCA-induced gastric mucous membrane intestinal metaplasia, we utilized the synthetic high-affinity FXR agonist GW4064 and FXR antagonist Gug. As shown in Fig. 5, compared with the control group, when GES-1 cells were treated with $400 \mu \mathrm{mol} / 1 \mathrm{DCA}$ for $6 \mathrm{~h}$, the expression levels of FXR, Cdx2 and MUC2 protein increased. However, the treatment of FXR agonist GW4064 significantly increased the expression levels of FXR, Cdx2 and MUC2 protein $(\mathrm{P}<0.01)$. By contrast, after FXR antagonist Gug. stimulation, the upregulation of DCA-induced FXR, Cdx2 and MUC2 expression was attenuated $(\mathrm{P}<0.05)$. The similar trend was also obtained 
A

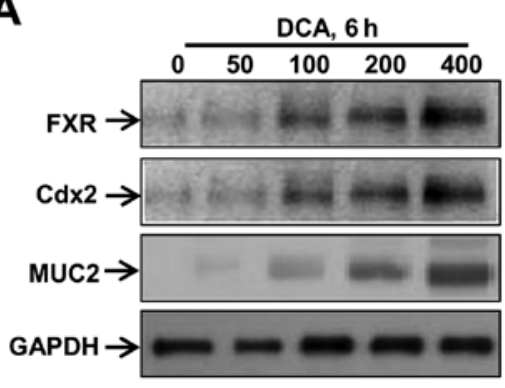

C

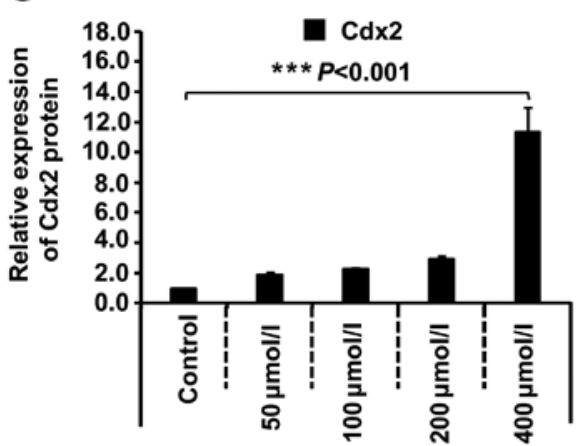

B

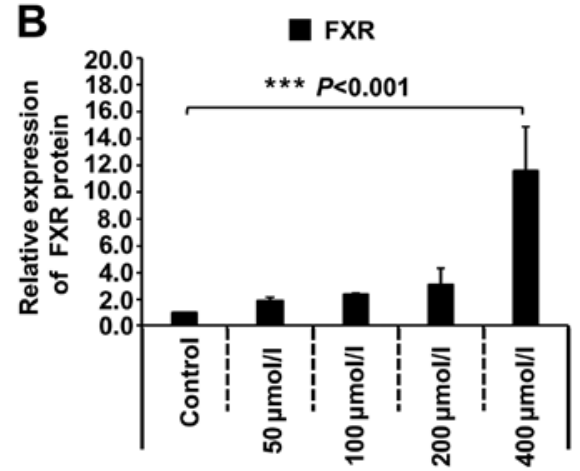

D

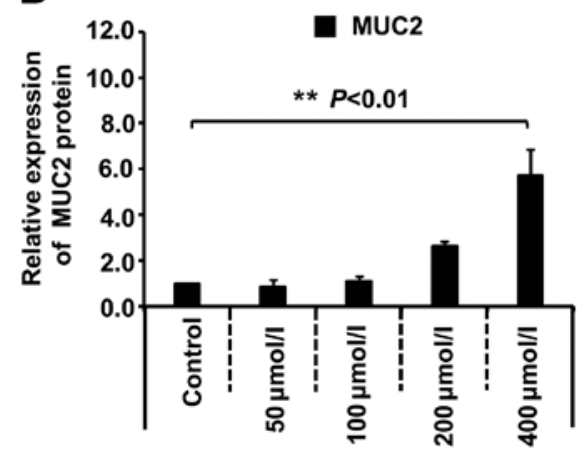

Figure 3. DCA induces the expression of FXR, Cdx2 and MUC2 protein in GES-1 cells. (A) GES-1 cells were cultured and treated with the DCA agent with the indicated concentrations $(50,100,200$ and $400 \mu \mathrm{mol} / \mathrm{l}$ ) or not (control), respectively, for $6 \mathrm{~h}$. The expression levels of FXR, Cdx2 and MUC2 protein were measured by western blotting. (B-D) Band density was digitized with TotalLab software, and the expression levels of FXR, Cdx 2 and MUC 2 protein were normalized against the GAPDH protein. One-way analysis of variance (ANOVA) was performed, and significant differences were indicated as follows: ${ }^{* * *} \mathrm{P}<0.001,{ }^{* * *} \mathrm{P}<0.01$. DCA, deoxycholic acid; FXR, farnesoid X receptor; Cdx2, caudal-related homeobox transcription factor 2; MUC2, mucin 2; GES-1, gastric epithelial cells.

A

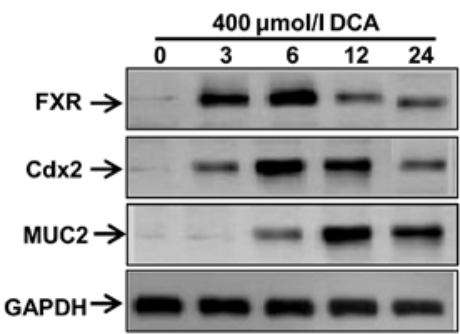

C

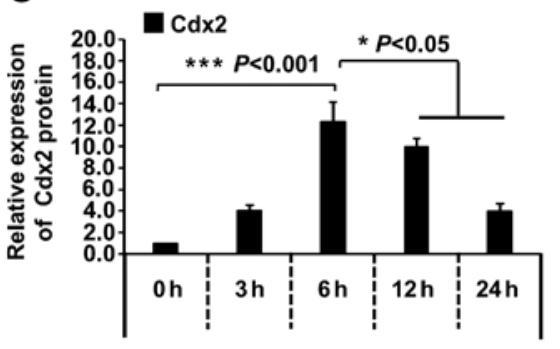

B

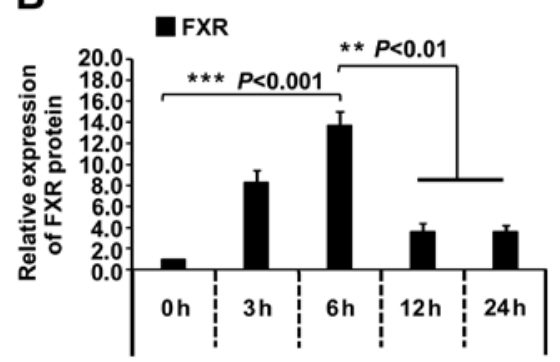

D

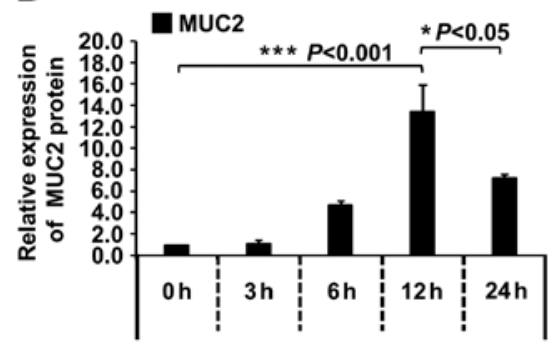

Figure 4. Effect of $400 \mu \mathrm{mol} / 1$ DCA on the expression of FXR, Cdx2 and MUC2 proteins in GES-1 cells. (A) GES-1 cells were cultured and treated with the $400 \mu \mathrm{mol} / 1 \mathrm{DCA}$ for the indicated time (0,3,6,12 and $24 \mathrm{~h}$ ), respectively. The expression levels of FXR, Cdx2 and MUC2 protein were measured by western blotting. (B-D) Band density was digitized with TotalLab software, and the expression levels of FXR, Cdx2 and MUC2 protein were normalized against the GAPDH protein. One-way analysis of variance (ANOVA) was performed, and significant differences were indicated as follows: ${ }^{*} \mathrm{P}<0.05,{ }^{* * *} \mathrm{P}<0.01,{ }^{* * * *} \mathrm{P}<0.001$. DCA, deoxycholic acid; FXR, farnesoid X receptor; Cdx2, caudal-related homeobox transcription factor 2; MUC2, mucin 2; GES-1, gastric epithelial cells.

in the measure of $F X R, C d x 2$ and $M U C 2$ mRNA levels (data not shown). These results demonstrated that DCA is capable of modulating the expression of $\mathrm{Cdx} 2$ and the downstream MUC2 via the nuclear receptor FXR. Additionally, FXR signaling pathway plays an important role in DCA-induced gastric intestinal metaplasia and carcinogenesis. 

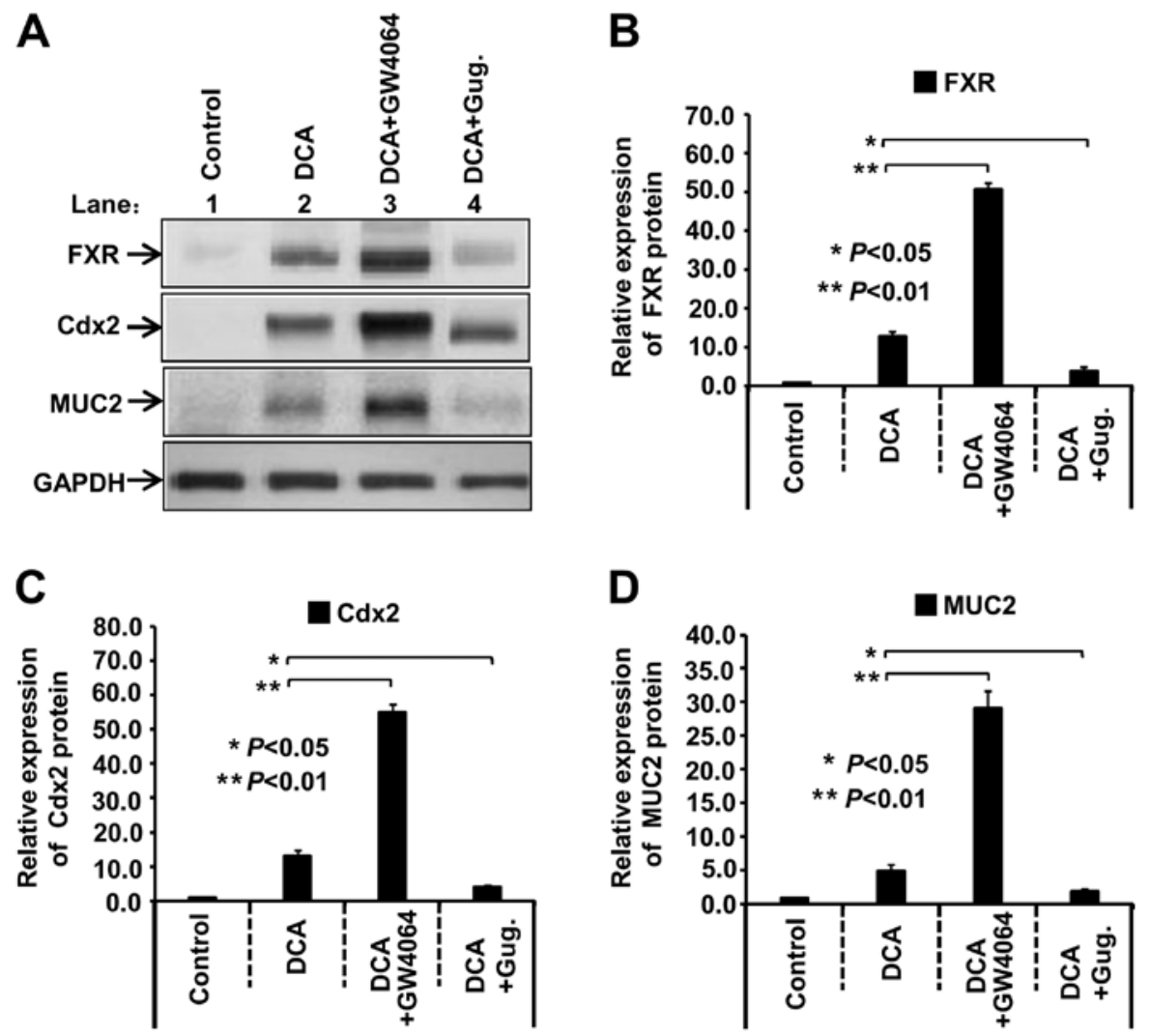

Figure 5. GW4064/guggulsterone (Gug.) affect the expression of FXR, Cdx2 and MUC2 in $400 \mu \mathrm{mol} / 1$ DCA-treated GES-1 cells. (A) GES-1 cells were cultured and treated with $400 \mu \mathrm{mol} / 1 \mathrm{DCA}, 400 \mu \mathrm{mol} / 1$ DCA plus $1.0 \mu \mathrm{mol} / 1 \mathrm{GW} 4064$ or $400 \mu \mathrm{mol} / 1 \mathrm{DCA}$ plus $50 \mu \mathrm{mol} / 1 \mathrm{Gug}$. for $6 \mathrm{~h}$, respectively. (B-D) Band density was digitized with TotalLab software, and the expression levels of FXR, Cdx2 and MUC2 protein were normalized against the GAPDH protein. One-way analysis of variance (ANOVA) was performed, and significant differences were indicated as: ${ }^{*} \mathrm{P}<0.05,{ }^{* *} \mathrm{P}<0.01$. FXR, farnesoid $\mathrm{X}$ receptor; Cdx2, caudal-related homeobox transcription factor 2; MUC2, mucin 2; DCA, deoxycholic acid; GES-1, gastric epithelial cells.

GW4064/Guggulsterone affect DCA-induced NF- $\kappa$ B activity and binding of the $C d x 2$ promoter and p50 protein. Moreover, we analyzed the association between FXR and NF- $\mathrm{KB}$ activity. GES-1 cells were co-transfected with pNF-кB-Luc and pRL-TK plasmid. After $18 \mathrm{~h}$, the cells were treated or not treated with $400 \mu \mathrm{mol} / 1 \mathrm{DCA}, 400 \mu \mathrm{mol} / 1 \mathrm{DCA}$ plus $1.0 \mu \mathrm{mol} / 1$ GW4064 or $400 \mu \mathrm{mol} / 1$ DCA plus $50 \mu \mathrm{mol} / 1 \mathrm{Gug}$. for $6 \mathrm{~h}$, respectively. The reporter activity was then measured. As shown in Fig. 6A, NF- $\mathrm{kB}$ activity in the GES-1 cells increased in response to DCA stimulation, compared with the control group $(\mathrm{P}<0.01)$. GW4064 enhanced the activity $(\mathrm{P}<0.05)$, whereas Gug. significantly reduced the activity $(\mathrm{P}<0.01)$, suggesting that DCA-induced FXR activation is closely related with the NF- $\mathrm{KB}$ activity. We then performed the CHIP assay to investigate the role of GW4064/Gug. in the association between $\mathrm{p} 50 / \mathrm{p} 65$ protein and $\mathrm{Cdx} 2$ promoter regions. As shown in Fig. 6B-C, the input of p50 and p65 increased in the DCA group, compared with the control group $(\mathrm{P}<0.001)$, which may be due to the nuclear location or upregulation of p50/p65 expression in response to the DCA stimulation. However, the DCA-induced increase of nuclear $\mathrm{p} 50 / \mathrm{p} 65$ protein was not affected by treatment with GW4064 or Gug. In addition, the precipitated nuclear p50 and p65 increased in the DCA group, compared with the control group (Fig. 6D). Thus, the amount of bound $\mathrm{Cdx} 2$ promoter fragment was normalized with the input fraction and the band density value of the enriched p50 and p65 protein. The results showed that DCA exposure enabled p50 protein to interact with the $\mathrm{Cdx} 2$ promoter (Fig. 6E, P<0.01) but not p65 (Fig 6F). GW4064 enhanced the binding activity of $\mathrm{p} 50$ protein and the $\mathrm{Cdx} 2$ promoter region (Fig. 6E, $\mathrm{P}<0.05$ ), By contrast, Gug. reduced the $\mathrm{Cdx} 2$ target region enriched by the p50 protein (Fig. $6 \mathrm{E}, \mathrm{P}<0.01$ ). These data demonstrated that DCA activated the FXR pathway and induced the expression of $\mathrm{Cdx} 2$ by stimulating the NF- $\mathrm{KB}$ mediated transcriptional activity of the $C d x 2$ promoter.

\section{Discussion}

Besides the intestinal system, kidneys, liver or adrenal glands, FXR exhibits a low expression level in the stomach, heart, lung and fat tissue $(9,11,12,27-29)$. In the present study, we observed FXR expression at a significantly lower level in cultured human GES-1 gastric mucosa cells and assessed the functional connection between bile acid-FXR pathway and intestinal metaplasia of gastric mucosa cells.

As the major cause of gastric mucosal injury, bile reflux is one of the risk factors for gastric cancer. However, the exact molecular mechanism remains elusive. CDCA, DCA and bile acid lithocholic acid are important ingredients that act as FXR ligands to activate the FXR pathway $(7,8)$. In order to mimic the bile reflux, CDCA or DCA is often used to treat gastric mucosal cells, and then further investigate the molecular mechanism. It was reported that activation of the FXR pathway in mice is able to resist the gastrointestinal 

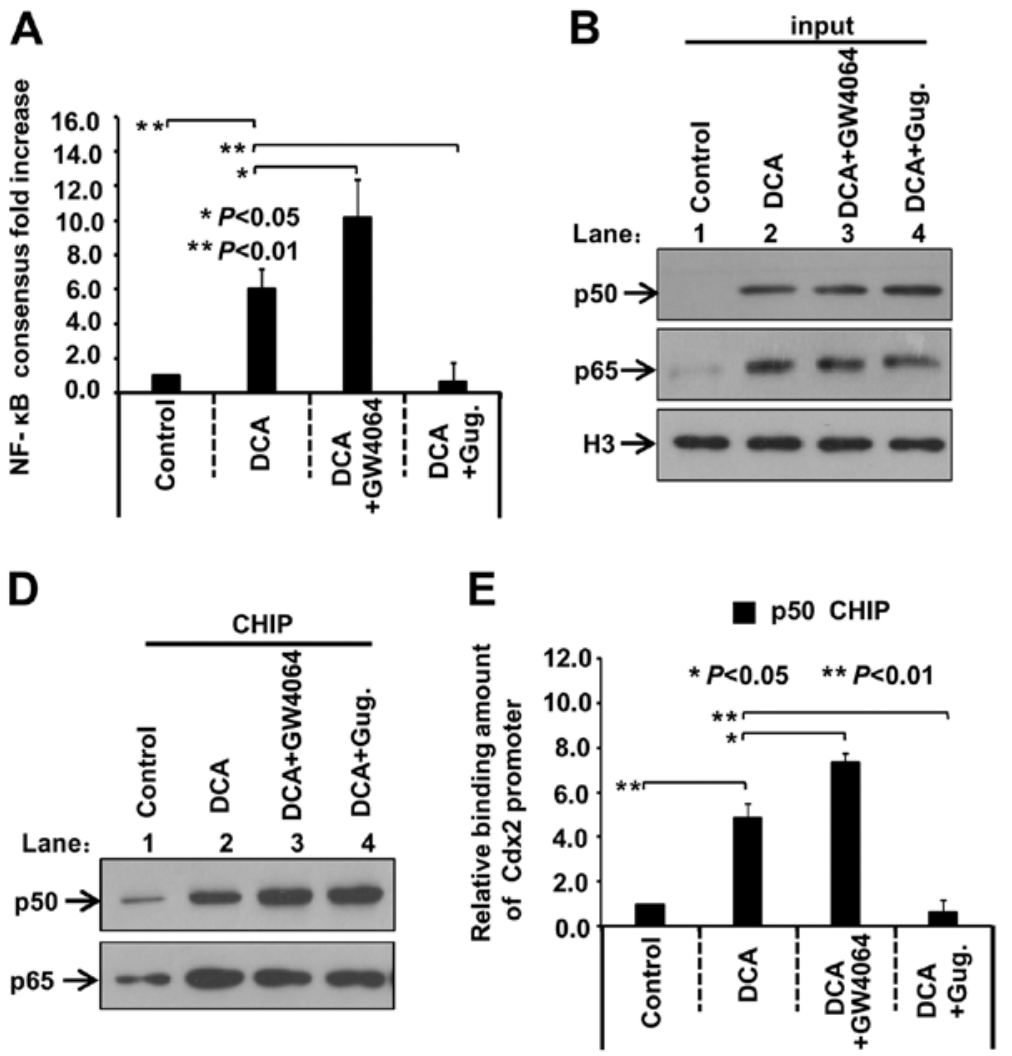
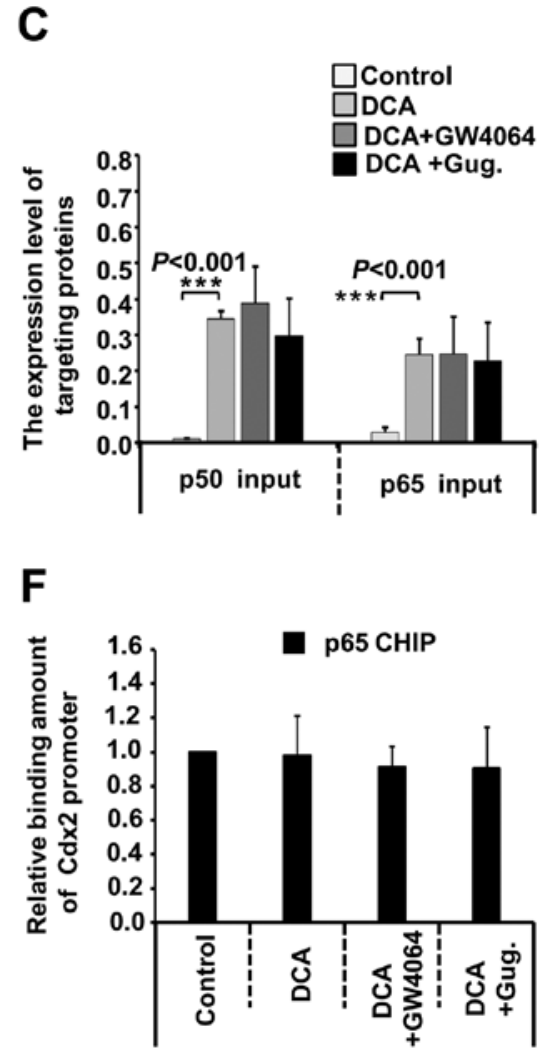

Figure 6. GW4064/guggulsterone (Gug.) affect DCA-induced NF- $\mathrm{kB}$ activity and the binding of Cdx2 promoter and p50 protein. (A) GES-1 cells were cultured and transfected with pNF-kB-Luc and pRL-TK plasmid using Lipofectamine 2000. After $18 \mathrm{~h}$, the cells were treated or not treated with $400 \mu \mathrm{mol} / 1 \mathrm{DCA}$, $400 \mu \mathrm{mol} / 1$ DCA plus $1.0 \mu \mathrm{mol} / 1 \mathrm{GW} 4064$ or $400 \mu \mathrm{mol} / 1$ DCA plus $50 \mu \mathrm{mol} / 1 \mathrm{Gug}$. for $6 \mathrm{~h}$, respectively. Reporter activity was then measured. (B-C) The chromatin immunoprecipitation (CHIP) assay was performed with the stimulated GES-1 cells, using anti-p50 and anti-p65 antibodies. Extracts (10\%) were included as input and measured by the western blotting using antibodies specific for $\mathrm{p} 50$ and p65. The histone H3 was used as a nuclear loading control. The levels of p50 and p65 were normalized against the corresponding H3 protein. (D-F) The enriched p50 or p65 proteins were detected via western blotting. Normal rabbit IgG was used as an isotype control. One-way analysis of variance (ANOVA) was performed and significant differences were indicated as follows: ${ }^{* * *} \mathrm{P}<0.001,{ }^{*} \mathrm{P}<0.05,{ }^{* *} \mathrm{P}<0.01$. DCA, deoxycholic acid; Cdx2, caudal-related homeobox transcription factor 2; GES-1, gastric epithelial cells.

mucosal damage of non-steroidal anti-inflammatory drugs (NSAIDs) (30). FXR functions to protect gastric epithelial cells against inflammation-mediated damage (11). Those findings suggest that proper stimulation of FXR serves as a type of protective mechanism for mucosa. However, in the present study, DCA was used to treat normal human GES-1 cells to mimic the bile reflux. We found that stimulation of the lowmoderate concentration of DCA on human GES-1 cells for a short period of time increased cell viability and activated the FXR pathway and the expression of $\mathrm{Cdx} 2$, the critical modulator of intestinal metaplasia in gastric mucosa, which is in concordance with the results obtained in a mouse model by $\mathrm{Xu}$ et al (7). The results indicated that activation of the FXR function differs in various ligands. In the intestinal system, FXR expression contributes to the normal cell function and inhibition of tumor promotion, whereas in stomach, abnormal FXR predisposes individuals to intestinal metaplasia in gastric mucosa and tumors occurrence.

Factors, such as NF- $\kappa B$ and MAPK pathways, contribute to the enhancement of $\mathrm{Cdx} 2$ expression $(15,18,31)$. The transcription factor NF- $\kappa \mathrm{B}$ activates the gene transcription of many cell processes, including inflammation, cell proliferation, differentiation and apoptosis $(32,33)$. A typical NF- $\kappa \mathrm{B}$ complex contains the heterologous dimer p50-p65 $(32,33)$. Under resting state, p50 and p65 are associated with the ІкB predominantly in the cytoplasm of the majority of cells. When treated with toxins, lipopolysaccharides, phospholipase A and

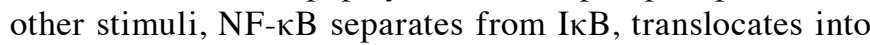
the nuclear compartment, and then binds to its target gene promoter or enhancer to regulate gene transcription $(32,33)$. It was reported that $C d x 2$ promoter contains NF- $\kappa \mathrm{B}$ binding sites, and can be combined with different subunits of NF- $\mathrm{KB}$. p65 and p50 exhibit different roles of transcriptional activity of $C d x 2(31,34,35)$. The translocation of NF- $\mathrm{KB}$ p 50 and p65 subunits is associated with the upregulation of $\mathrm{Cdx} 2$, and the binding of p50 subunit with the $C d x 2$ promoter fragment leads to an increase in the promoter activity of $C d x 2$ in human esophageal cells $(34,36)$. In the present study, we also observed activation of the NF- $\mathrm{kB}$ pathway in the DCA-treated human GES-1 cells. Additionally, the binding activity of NF- $\kappa B$ p50 protein and $C d x 2$ gene can be affected by the FXR pathway inhibitors or activators. This effect means that the NF- $\mathrm{KB}$ pathway is involved in the upregulation of $\mathrm{Cdx} 2$ expression in the DCA-induced FXR pathway activation, resulting in intestinal metaplasia of gastric mucosa.

Previous studies have shown that activated $\mathrm{Cdx} 2$ plays a role in the intestinal metaplasia of gastric mucosa and gastric tumorigenesis through the association with the expression of claudin-3 and -4, cyclooxygenase-2 (COX-2), Sonic hedgehog (Shh) or mutations of p53, and APC genes (19,37-39). For 
example, the homeobox protein $\mathrm{Cdx} 2$ reduces Cox- 2 transcription by inactivating the DNA-binding capacity of NF- $\kappa \mathrm{B}$ (39). $\mathrm{Cdx} 2$ was reported to enhance significantly the expression of $M U C 2$ mRNA via binding to the $M U C 2$ gene promoter (26). The present study has shown that the expression levels of $\mathrm{Cdx} 2$ and MUC2 were enhanced by the DCA-induced FXR signal. The highest expression level of MUC2 was at $12 \mathrm{~h}$, later than FXR and Cdx2, which is in concordance with the results of $\mathrm{Xu}$ et al (7). It is possible that DCA exposure first leads to the upregulation of FXR and $\mathrm{Cdx} 2$ expression, which then increases the expression of MUC2 in GES-1 cells. Similarly, the expression of other intestinal genes, such as CDX1 and defensin-5, also delayed the $\mathrm{Cdx} 2$ protein in human gastric mucosa with intestinal metaplasia (40). The findings suggest that DCA-induced FXR-Cdx2 pathway is involved in the intestinal metaplasia of gastric mucosa, the premalignant lesion of the intestinal type of gastric cancer.

Chronic bile reflux, a common phenomenon after subtotal gastrectomy, aggravates the damage of gastric and esophageal mucosa, and even results in the occurence of gastric ulcer, gastric cancer, Barrett's esophagus and esophageal cancer $(4,41,42)$. $\mathrm{Cdx} 2$ protein is not expressed in normal gastric mucosa. However, long-standing bile reflux alters the microenvironment of the gastric mucosa through many factors, such as bile and gastric acid and $\mathrm{Hp}$, and thus form a type of microenvironment, similar to the gut. Such a microenvironment contributes to the activation of FXR or the $\mathrm{NF}-\kappa \mathrm{B}$ signaling pathway. $\mathrm{Cdx} 2$ protein regulates intestinal gene expression in intestinal metaplasia of gastric mucosa. However, the role of $\mathrm{Cdx} 2$ protein in the pathogenesis of cancer remains to be elucidated and may be tissue-specific.

Upregulation of $\mathrm{Cdx} 2$ inhibits proliferation of the MGC-803 gastric cancer cell line in vitro (43). Cdx2 was also reported to repress the proliferation of pancreatic cancer cells through the modulation of cyclin D1 transcriptional activity (44). These results suggest that $C d x 2$ functions as the tumor-suppressor gene. It is speculated that, in the early stage, ectopic expression of $\mathrm{Cdx} 2$ acts as the original cause of intestinal metaplasia, and maintains the intestinal phenotype of gastric cells to repress the malignant progression. Along with the enhancement of the extracellular stimuli, such a role of $\mathrm{Cdx} 2$ was disturbed, and the precancerous lesion of gastric mucosa was then transformed into gastric cancer. With the increase of the malignant or differentiated extent of tumor tissues, Cdx2 is downregulated or mutated $(13,19-21,45)$. Therefore, assessing and providing appropriate interventions on the aberrant expression phase of FXR, CDX2 or MUC2, the related gene mutation in gastric precancerous lesion and cancer contributes to the early diagnosis of gastric cancer with the intestinal type, the judgment of malignant degree, or even the preventiion or reversal of gastric intestinal metaplasia in patients. In the present study, the experiment based on the cell culture model was not effective for the detection of FXR, CDX2 or MUC2 expression phase changes. More experiments using clinical samples are to be performed in our laboratory to verify the results obtained.

In summary, the stimulation of DCA is capable of inducing the ectopic expression of $\mathrm{Cdx} 2$ and MUC2 in human gastric epithelial cells via FXR-mediated estrogen receptor activation and FXR-associated NF- $\mathrm{B}$ activity. DCA, a key biological sensor or metabolic regulator, acts as the activator of gastric mucosa FXR and causes intestinal metaplasia. This plays an important role in the intestinal metaplasia of gastric mucosa induced by bile reflux, which is involved in the dysplasia or carcinogenesis of gastric mucosa.

\section{Acknowledgements}

The present study was supported by a grant from the National Natural Science Foundation of China (no. 81200261), and a grant from the Science and Technology Fund Project of Tianjin Health Bureau (07K222).

\section{References}

1. Park JY, von Karsa L and Herrero R: Prevention strategies for gastric cancer: A global perspective. Clin Endosc 47: 478-489, 2014.

2. Correa P, Piazuelo MB and Wilson KT: Pathology of gastric intestinal metaplasia: Clinical implications. Am J Gastroenterol 105: 493-498, 2010.

3. Dinis-Ribeiro M, Areia M, de Vries AC, Marcos-Pinto R, Monteiro-Soares M, O'Connor A, Pereira C, Pimentel-Nunes P, Correia R, Ensari A, et al; European Society of Gastrointestinal Endoscopy; European Helicobacter Study Group; European Society of Pathology; Sociedade Portuguesa de Endoscopia Digestiva: Management of precancerous conditions and lesions in the stomach (MAPS): Guideline from the European Society of Gastrointestinal Endoscopy (ESGE), European Helicobacter Study Group (EHSG), European Society of Pathology (ESP), and the Sociedade Portuguesa de Endoscopia Digestiva (SPED). Endoscopy 44: 74-94, 2012.

4. Dixon MF, Mapstone NP, Neville PM, Moayyedi P and Axon AT: Bile reflux gastritis and intestinal metaplasia at the cardia. Gut 51: 351-355, 2002.

5. Martinez-Augustin O and Sanchez de Medina F: Intestinal bile acid physiology and pathophysiology. World J Gastroenterol 14: 5630-5640, 2008.

6. Huo X, Juergens S, Zhang X, Rezaei D, Yu C, Strauch ED, Wang JY, Cheng E, Meyer F, Wang DH, et al: Deoxycholic acid causes DNA damage while inducing apoptotic resistance through NF- $\kappa \mathrm{B}$ activation in benign Barrett's epithelial cells. Am J Physiol Gastrointest Liver Physiol 301: G278-G286, 2011.

7. Xu Y, Watanabe T, Tanigawa T, Machida H, Okazaki H, Yamagami H, Watanabe K, Tominaga K, Fujiwara Y, Oshitani N, et al: Bile acids induce cdx2 expression through the farnesoid $\mathrm{x}$ receptor in gastric epithelial cells. J Clin Biochem Nutr 46: 81-86, 2010.

8. Mazuy C, Helleboid A, Staels B and Lefebvre P: Nuclear bile acid signaling through the farnesoid $\mathrm{X}$ receptor. Cell Mol Life Sci 72: 1631-1650, 2015.

9. Matsubara T, Li F and Gonzalez FJ: FXR signaling in the enterohepatic system. Mol Cell Endocrinol 368: 17-29, 2013.

10. Li S, Ni A and Feng GS: Bridging cell surface receptor with nuclear receptors in control of bile acid homeostasis. Acta Pharmacol Sin 36: 113-118, 2015.

11. Lian F, Xing X, Yuan G, Schäfer C, Rauser S, Walch A, Röcken C, Ebeling M, Wright MB, Schmid RM, et al: Farnesoid $X$ receptor protects human and murine gastric epithelial cells against inflammation-induced damage. Biochem J 438: 315-323, 2011.

12. Shaik FB, Prasad DV and Narala VR: Role of farnesoid X receptor in inflammation and resolution. Inflamm Res 64: 9-20, 2015.

13. Yan LH, Wei WY, Xie YB and Xiao Q: New insights into the functions and localization of the homeotic gene $C D X 2$ in gastric cancer. World J Gastroenterol 20: 3960-3966, 2014.

14. Kerkhof M, Bax DA, Moons LM, van Vuuren AJ, van Dekken H, Steyerberg EW, Kuipers EJ, Kusters JG, Siersema PD; Cybar Study Group: Does CDX2 expression predict Barrett's metaplasia in oesophageal columnar epithelium without goblet cells? Aliment Pharmacol Ther 24: 1613-1621, 2006.

15. Coskun M, Troelsen JT and Nielsen OH: The role of CDX2 in intestinal homeostasis and inflammation. Biochim Biophys Acta 1812: 283-289, 2011. 
16. Roessler K, Mönig SP, Schneider PM, Hanisch FG, Landsberg S, Thiele J, Hölscher AH, Dienes HP and Baldus SE: Co-expression of CDX2 and MUC2 in gastric carcinomas: Correlations with clinico-pathological parameters and prognosis. World J Gastroenterol 11: 3182-3188, 2005.

17. Boyd M, Hansen M, Jensen TG, Perearnau A, Olsen AK, Bram LL, Bak M, Tommerup N, Olsen J and Troelsen JT: Genome-wide analysis of CDX2 binding in intestinal epithelial cells (Caco-2). J Biol Chem 285: 25115-25125, 2010

18. Houde M, Laprise P, Jean D, Blais M, Asselin C and Rivard N: Intestinal epithelial cell differentiation involves activation of p38 mitogen-activated protein kinase that regulates the homeobox transcription factor CDX2. J Biol Chem 276: 21885-21894, 2001

19. Mutoh H, Sakurai S, Satoh K, Tamada K, Kita H, Osawa H, Tomiyama T, Sato Y, Yamamoto H, Isoda N, et al: Development of gastric carcinoma from intestinal metaplasia in $\mathrm{Cdx} 2$-transgenic mice. Cancer Res 64: 7740-7747, 2004.

20. Liu Q, Teh M, Ito K, Shah N, Ito Y and Yeoh KG: CDX2 expression is progressively decreased in human gastric intestinal metaplasia, dysplasia and cancer. Mod Pathol 20: 1286-1297, 2007.

21. Park Y, Srivastava A, Kim GH, Mino-Kenudson M, Deshpande V, Zukerberg LR, Song GA and Lauwers GY: CDX2 expression in the intestinal-type gastric epithelial neoplasia: Frequency and significance. Mod Pathol 23: 54-61, 2010.

22. Mutoh H, Satoh K, Kita H, Sakamoto H, Hayakawa $H$ Yamamoto H, Isoda N, Tamada K, Ido K and Sugano K: Cdx2 specifies the differentiation of morphological as well as functional absorptive enterocytes of the small intestine. Int J Dev Biol 49: 867-871, 2005.

23. Silberg DG, Sullivan J, Kang E, Swain GP, Moffett J, Sund NJ, Sackett SD and Kaestner KH: Cdx2 ectopic expression induces gastric intestinal metaplasia in transgenic mice. Gastroenterology 122: 689-696, 2002.

24. Johansson ME and Hansson GC: Mucus and the goblet cell. Dig Dis 31: 305-309, 2013

25. Johansson ME, Sjövall $\mathrm{H}$ and Hansson GC: The gastrointestinal mucus system in health and disease. Nat Rev Gastroenterol Hepatol 10: 352-361, 2013.

26. Yamamoto H, Bai YQ and Yuasa Y: Homeodomain protein CDX2 regulates goblet-specific MUC2 gene expression. Biochem Biophys Res Commun 300: 813-818, 2003.

27. Huang XF, Zhao WY and Huang WD: FXR and liver carcinogenesis. Acta Pharmacol Sin 36: 37-43, 2015.

28. van de Winkel A, van Zoest KP, van Dekken H, Moons LM, Kuipers EJ and van der Laan LJ: Differential expression of the nuclear receptors farnesoid X receptor (FXR) and pregnane $X$ receptor (PXR) for grading dysplasia in patients with Barrett's oesophagus. Histopathology 58: 246-253, 2011.

29. Khurana S, Raufman JP and Pallone TL: Bile acids regulate cardiovascular function. Clin Transl Sci 4: 210-218, 2011.

30. Fiorucci S, Mencarelli A, Cipriani S, Renga B, Palladino G Santucci L and Distrutti E: Activation of the farnesoid-X receptor protects against gastrointestinal injury caused by nonsteroidal anti-inflammatory drugs in mice. Br J Pharmacol 164: 1929-1938, 2011.
31. Kim S, Domon-Dell C, Wang Q, Chung DH, Di Cristofano A, Pandolfi PP, Freund JN and Evers BM: PTEN and TNF-alpha regulation of the intestinal-specific $\mathrm{Cdx}-2$ homeobox gene through a PI3K, PKB/Akt, and NF-kappaB-dependent pathway. Gastroenterology 123: 1163-1178, 2002.

32. Jing $\mathrm{H}$ and Lee $\mathrm{S}: \mathrm{NF}-\kappa \mathrm{B}$ in cellular senescence and cancer treatment. Mol Cells 37: 189-195, 2014.

33. Chen LF and Greene WC: Shaping the nuclear action of NF-kappaB. Nat Rev Mol Cell Biol 5: 392-401, 2004.

34. Debruyne PR, Witek M, Gong L, Birbe R, Chervoneva I, Jin T, Domon-Cell C, Palazzo JP, Freund JN, Li P, et al: Bile acids induce ectopic expression of intestinal guanylyl cyclase $\mathrm{C}$ through nuclear factor-kappaB and $\mathrm{Cdx} 2$ in human esophageal cells. Gastroenterology 130: 1191-1206, 2006.

35. Kazumori H, Ishihara S, Rumi MA, Kadowaki Y and Kinoshita Y. Bile acids directly augment caudal related homeobox gene Cdx2 expression in oesophageal keratinocytes in Barrett's epithelium. Gut 55: 16-25, 2006.

36. Huo X, Zhang HY, Zhang XI, Lynch JP, Strauch ED, Wang JY, Melton SD, Genta RM, Wang DH, Spechler SJ, et al: Acid and bile salt-induced CDX2 expression differs in esophageal squamous cells from patients with and without Barrett's esophagus. Gastroenterology 139: 194-203.e1, 2010.

37. Satake S, Semba S, Matsuda Y, Usami Y, Chiba H, Sawada N, Kasuga $M$ and Yokozaki H: Cdx2 transcription factor regulates claudin-3 and claudin-4 expression during intestinal differentiation of gastric carcinoma. Pathol Int 58: 156-163, 2008.

38. Mutoh H, Hayakawa H, Sashikawa M, Sakamoto H and Sugano K: Direct repression of Sonic Hedgehog expression in the stomach by $\mathrm{Cdx} 2$ leads to intestinal transformation. Biochem J 427: 423-434, 2010.

39. Mutoh H, Hayakawa H, Sakamoto H and Sugano K: Homeobox protein CDX2 reduces Cox 2 transcription by inactivating the DNA-binding capacity of nuclear factor-kappaB. J Gastroenterol 42: 719-729, 2007.

40. Eda A, Osawa H, Yanaka I, Satoh K, Mutoh H, Kihira K and Sugano K: Expression of homeobox gene CDX2 precedes that of CDX1 during the progression of intestinal metaplasia. J Gastroenterol 37: 94-100, 2002

41. Zaninotto G, Portale G, Parenti A, Lanza C, Costantini M, Molena D, Ruol A, Battaglia G, Costantino M, Epifani M, et al: Role of acid and bile reflux in development of specialised intestinal metaplasia in distal oesophagus. Dig Liver Dis 34: 251-257, 2002.

42. Weijenborg PW and Bredenoord AJ: How reflux causes symptoms: Reflux perception in gastroesophageal reflux disease. Best Pract Res Clin Gastroenterol 27: 353-364, 2013.

43. Xie Y, Li L, Wang X, Qin Y, Qian Q, Yuan X and Xiao Q: Overexpression of $\mathrm{Cdx} 2$ inhibits progression of gastric cancer in vitro. Int J Oncol 36: 509-516, 2010.

44. Takahashi K, Hirano F, Matsumoto K, Aso K and Haneda M: Homeobox gene CDX2 inhibits human pancreatic cancer cell proliferation by down-regulating cyclin D1 transcriptional activity. Pancreas 38: 49-57, 2009.

45. Song JH, Kim CJ, Cho YG, Chae JS, Cao Z, Nam SW, Lee JY and Park WS: Genetic alterations of the $C d x 2$ gene in gastric cancer. APMIS 116: 74-80, 2008. 